\title{
Lung Metastatic Nodules as First Presentation of Synovial Cardiac Sarcoma
}

\author{
F Ampatzidou ${ }^{1 *}$, T Karaiskos ${ }^{1}$, K Vasiliadis ${ }^{2}$, A Cheva ${ }^{3}$, CP Koutsogiannidis ${ }^{1}$, A Madesis ${ }^{1}$, M Sileli ${ }^{1}$, G Drossos ${ }^{1}$ \\ From World Society of Cardiothoracic Surgeons 25th Anniversary Congress, Edinburgh \\ Edinburgh, UK. 19-22 September 2015
}

\section{Background/Introduction}

Synovial sarcomas are rare tumors accounting for approximately $1 \%$ from all cardiac neoplasms and present with a variety of symptoms depending on their location and size.

\section{Aims/Objectives}

To describe a unique case of a 36 year old male presenting with bilaterally pulmonary nodules as a result of right heart synovial sarcoma.

\section{Method}

Video-assisted thoracoscopic biopsy (due to newly diagnosed pulmonary nodules) revealed mesenchymal malignant neoplasm. Echocardiography showed a large mass located in the right atrium, arising from the anterior tricuspid valve. [Fig 1] Magnetic resonance imaging (MRI) of the heart demonstrated further anatomic details.18F PET-CT scan revealed increased tracer uptake in lung nodule and in lytic lesion of the 8th thoracic vertebrae body indicating a spinal cord metastasis [Fig 2].

\section{Results}

The patient underwent median sternotomy and aortobicaval cannulation. After longitudinally opening of the right atrium, a $6-\mathrm{cm}$ long pedunculated tumor originating from the atrial wall and part of the septal cusp of the tricuspid valve was identified. The tumor was completely resected with part of the invaded cusp. [Fig 3] The septal cusp was repaired with pericardial patch and tricuspid valve repair was completed with the placement

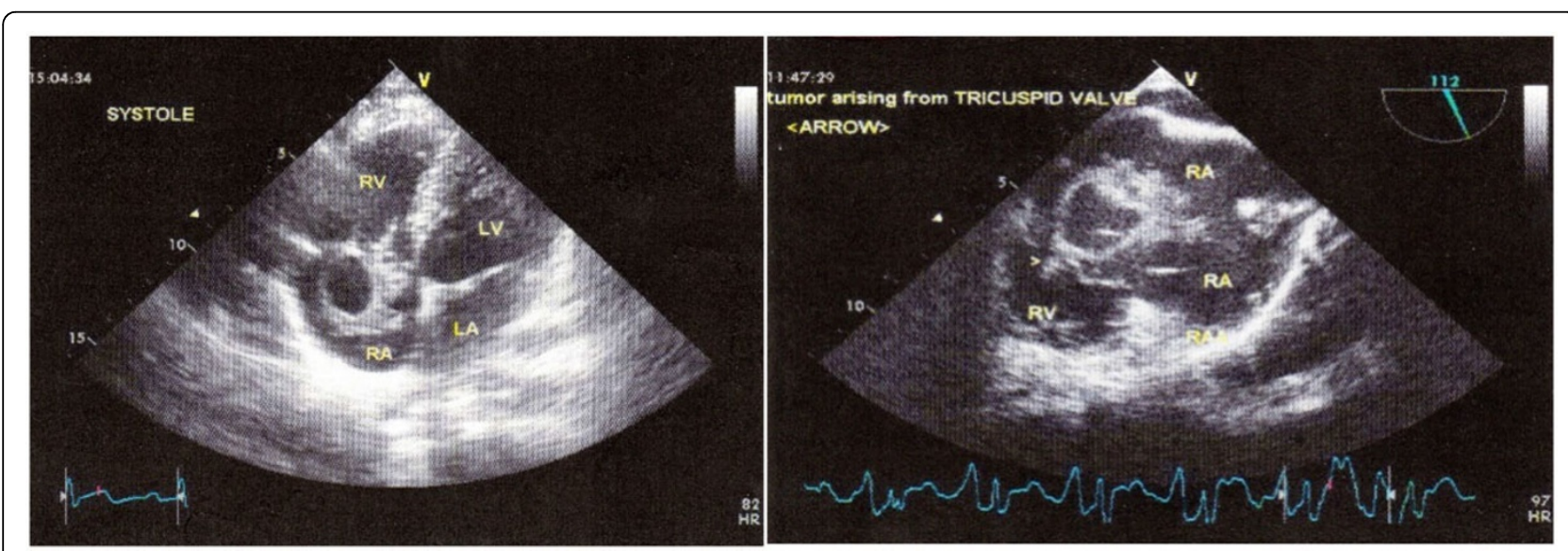

Figure 1 TTE-TEE Echocardiography: Right atrial mass.

${ }^{1}$ Cardiothoracic Surgery Department, G. Papanikolaou Hospital, Thessaloniki,

57010, Greece

Full list of author information is available at the end of the article

(c) 2015 Ampatzidou et al. This is an Open Access article distributed under the terms of the Creative Commons Attribution License (http://creativecommons.org/licenses/by/4.0), which permits unrestricted use, distribution, and reproduction in any medium, provided the original work is properly cited. The Creative Commons Public Domain Dedication waiver (http://creativecommons.org/ publicdomain/zero/1.0/) applies to the data made available in this article, unless otherwise stated. 


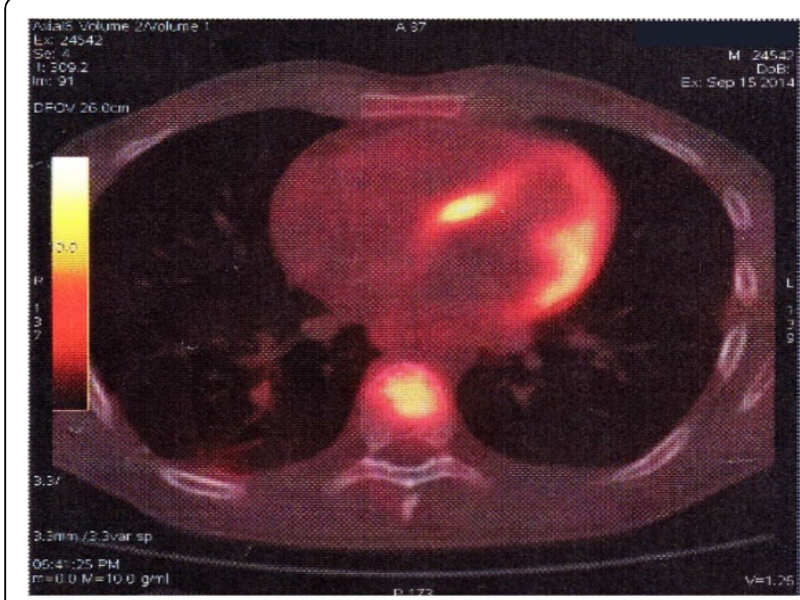

Figure 2 18F PET-CT scan. Lytic lesionin thoracic vertebrae body.

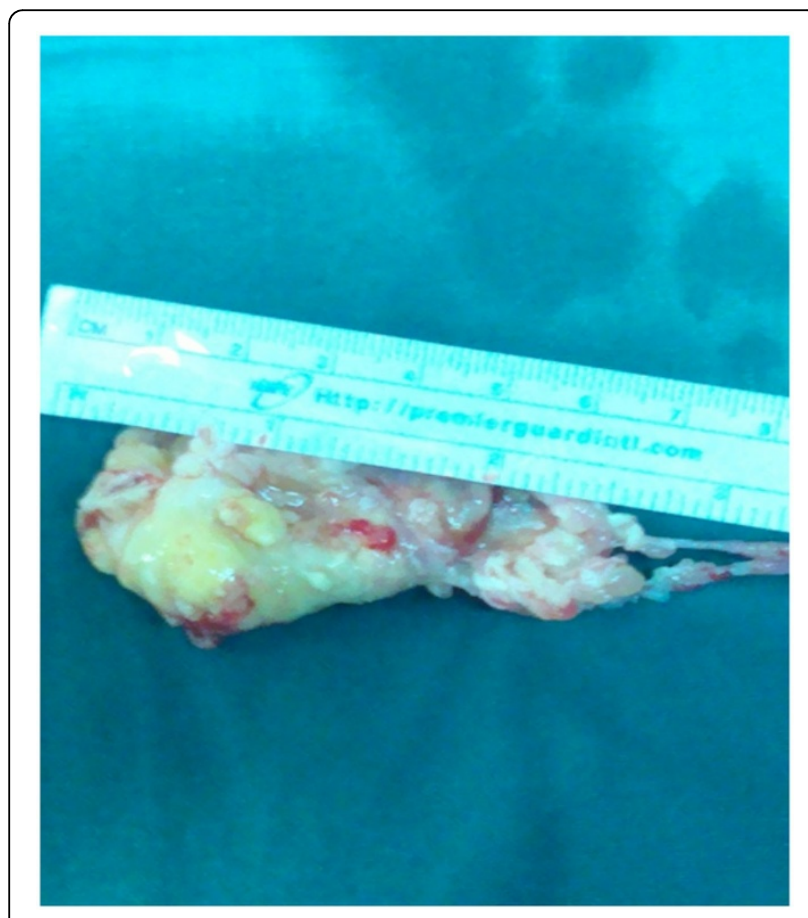

Figure 3 Excised mass, $6 \mathrm{~cm}$ long

of annuloplasty ring. The left lower lobe nodule was excised with wedge resection, while the nodules of the left upper lobe and the right lower lobe were ablated with a radiofrequency device because of their central location. The patient was discharged uneventfully on the 6th postoperative day.

Histopathologic testing results, showed neoplastic infiltration by spindle-like cells with dense arrangement, large nuclei, atypia, polymorphism and increased mitotic

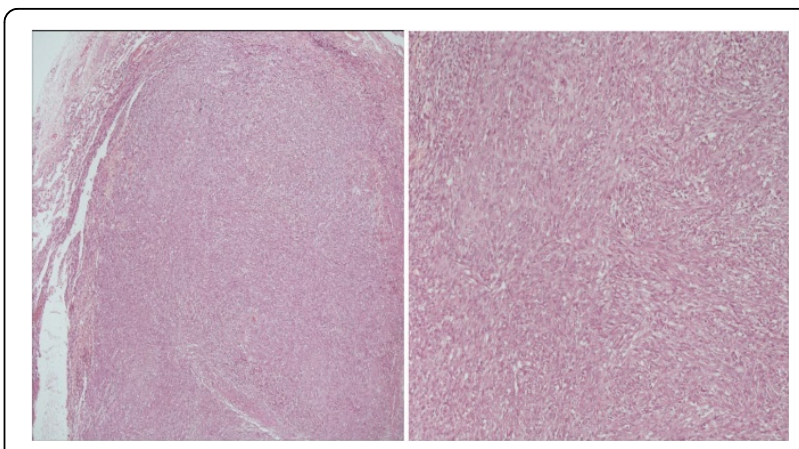

Figure 4 Histopathologic image: Monophasic synovial sarcoma. Hematoxylin-eosin staining of tissue showing the characteristic infiltration by spindle-like cells with dense arrangement and large nuclei.

rate. Findings were indicative of monophasic synovial sarcoma mainly from spindle cells [Fig 4].

\section{Discussion/Conclusion}

We present a unique case of a patient with synovial sarcoma with pulmonary nodules as first manifestation.

\section{Consent}

Written informed consent was obtained from the patient for publication of this abstract and any accompanying images. A copy of the written consent is available for review by the Editor of this journal.

\section{Authors' details}

${ }^{1}$ Cardiothoracic Surgery Department, G. Papanikolaou Hospital, Thessaloniki, 57010, Greece. ${ }^{2}$ Cardiology Department, G. Papanikolaou Hospital, Thessaloniki, 57010, Greece. ${ }^{3}$ Histopathology Department, G. Papanikolaou Hospital, Thessaloniki, 57010, Greece.

Published: 16 December 2015

doi:10.1186/1749-8090-10-S1-A327

Cite this article as: Ampatzidou et al:: Lung Metastatic Nodules as First Presentation of Synovial Cardiac Sarcoma. Journal of Cardiothoracic Surgery 2015 10(Suppl 1):A327.

\section{Submit your next manuscript to BioMed Central and take full advantage of:}

- Convenient online submission

- Thorough peer review

- No space constraints or color figure charges

- Immediate publication on acceptance

- Inclusion in PubMed, CAS, Scopus and Google Scholar

- Research which is freely available for redistribution 